Digital Press Social Sciences and Humanities

Optimization of Community Empowerment Through Improving the Potential of the Community in The New Normal Era

Nurul Hayati

Proceeding of The Non-Formal Education International Conference 2020

Alim Harun Pamungkas, Jamaris, Solfema (eds) 


\title{
Optimization of Community Empowerment Through Improving the Potential of the Community in The New Normal Era
}

\author{
Nurul Hayati \\ Department of Non-Formal Education Universitas Negeri Padang, Padang, Indonesia \\ e-mail: nurul.yoga27@gmail.com
}

\begin{abstract}
The community is one of the sectors that is heavily affected by the situation due to the Covid-19 pandemic. Starting from urban communities to rural communities, they are required to be able to adapt to changes that have occurred due to the outbreak of the Covid-19 virus. During the Covid-19 pandemic, it was not only the order of people's lives that changed from previously all activities could be carried out freely outside the home without being restricted by anything, but the current condition is that all activities are limited, for activities outside the home must comply with the Covid-19 health protocol . This has a profound impact on the welfare of the community, with restrictions on activities outside the home making people helpless, many employees or laborers are laid off, the economy deteriorates. In response to the spread of the Covid-19 virus, it has entered a new normal life. This research tries to elaborate on this phenomenon, especially related to the optimization of empowerment as an effort to increase the potential of people in the new normal era. The method used is literature study. The findings in this study, namely that in community empowerment in the new normal era, it can be optimized by developing all the potential of the community, the government can work together with the community in adapting behavior in the new normal era.
\end{abstract}

\section{Keywords}

community empowerment, community potential, new normal

\section{Introduction}

Since the outbreak of Corona Virus Disease 2019 (Covid-19) in Wuhan City, China until the emergence of the first case of the Covid-19 pandemic in Indonesia on March 11, 2020 (Azizah, 2020; Friana, 2020; Hatta, 2020). The Indonesian government has taken several policy steps in terminating and preventing the transmission of Covid-19. The policies in question, such as the issuance of the Decree of the Head of the National Disaster Management Agency Number A of 2020 concerning the Determination of the Status of Certain Disaster Emergency Conditions for Corona Virus Outbreaks in Indonesia which are valid from 28 January 2020 to 28 February 2020, which was later extended to May 29, 2020, campaigning for social distancing (social restrictions) (Davina, 2020), which was later revised to physical distancing (maintaining physical distance) (Taher, 2020; Yahya, 2020). The issuance of Government Regulation (PP) Number 21 of 2020 concerning Large-Scale Social Restrictions in the Context of the Acceleration of Handling Corona Virus Disease 2019 (Covid-19) which emphasizes school and workplace holidays; restrictions on religious activities; and/or restrictions on activities in public places or facilities (President of the Republic of Indonesia, 2019), and the policy of transition to normal until the new normal is implemented (Akbar \& Benedict, 2020; Habibi, 2020; Muhyiddin, 2020; Prabawanti, 2020).

This series of policies requires the public to obey all the policies and regulations that have been established in efforts to deal with and deal with the Covid-19 pandemic, starting from home quarantine, self-isolation, quarantine of special facilities, hospital quarantine, and regional quarantine. Now, the government has prepared a protocol for the New Normal scenario in various lines, as released by the WHO Indonesia Situation Report on June 10, 2020, while WHO also continues to support the government in analyzing provincial data to assess epidemiological criteria related to Large-Scale Social Restrictions (PSBB). 
The standards for determining the New Normal that were stated by WHO, include the speed of isolation measures for confirmed cases, appropriate clinical care for PDP, speed for extensive contact tracing and quarantine of all contacts, and habit of frequent hand washing; wearing masks in public places and workplaces; as well as maintaining physical distance between community members. It becomes a question, how long do people and their various sectors of life have to live in a time of uncertainty, discomfort and insecurity from a pandemic situation. Responding to the situation and conditions that occur, the new normal life order becomes an alternative exit strategy. In this context, New Normal is actually intended as an era of adaptation of various sectors of people's life amid the Covid-19 pandemic, both in urban and rural areas (Arwani, 2020).

Measuring the readiness of the community in facing the New Normal Era, at least it can be seen from the perspective of community power which can support and strengthen each other so that the existence of the community really proves itself as a support for national development and progress in all conditions. New normal is intended so that the various sectors of life that had been choked up and even stopped can (slightly) move back. In other words, adapting to life in a pandemic emergency is an effort to reduce the rate of social vulnerability in an uncertain society. The community empowerment pattern is a form of effort taken by the government to develop, independent and empower the community to be able to make changes that aim to improve the quality of regional potential. Based on this explanation,

Indonesia is a country that has abundant wealth. The existence of these abundant resources becomes the capital in building and increasing community empowerment (Hasanah, 2015), Widayanti (2012), suggests that community empowerment is a public concern and is considered as one of the appropriate approaches in overcoming social problems, especially poverty, which is carried out by various elements ranging from government, business and society through organizations. Law number 6 of 2014 concerning villages article 1 paragraph 12 explains that empowerment of village communities is an effort to develop independence and community welfare by increasing knowledge, attitudes, skills, behavior, abilities, awareness, and utilizing resources through the establishment of policies, programs, activities and assistance in accordance with the essence of the problem and the priority needs of the community. In an effort to empower the community, it is necessary to realize the understanding that the emergence of community powerlessness is the result of the community having no power (powerless). Community empowerment is a development carried out for the community by increasing the ability to determine their future and participate in influencing their lives (Simamora, 2020).

Thus, community empowerment is a development carried out for the community by increasing the ability to determine their own future and participate in influencing their own lives. Entering the new normal era, the implementation of community empowerment is required to adapt and change old patterns. If the previous community empowerment approach was such as meeting with the community face-to-face and attended by many people, now it is starting to adapt by limiting each community meeting as well as additional health protocols that must be implemented in the community. Other changes are restrictions on working hours, activities outside the home, using masks in every activity outside the home and always washing hands every time you go out of the house.

Based on the phenomena described above, researchers will conduct related research optimizing community empowerment as an effort to increase community potential in the new normal era. For researchers to formulate several questions to explain this, namely how does the Covid-19 pandemic affect community empowerment? How is the renewal of community empowerment in the new normal era? What forms of empowerment can increase the potential of the community in the new normal era?

\section{Methods}

This research is a literature study method. Library research or (library research) is a research method that emphasizes a series of library data collection activities, reading and taking notes and processing research materials (Zed, 2014). According to Sugiyono (2014) literature study is a theoretical study, references and other scientific literature related to the culture, values and norms that develop in the social situation under study. Further according to Nazir (2014) Literature study is a technique of collecting data by conducting study studies of books, literatures, notes and reports that are related to the problem being solved. So broadly speaking, library research limits its activities to library collection materials only without the need for field research.

Literature research has four main characteristics, namely first, the writer or researcher is dealing directly with text or numerical data, not with direct knowledge from the field. Second, library data is 
"ready to use". Third, that library data is generally a secondary source, in the sense that the researcher obtains material or data from second hand and not original data from the first data in the field. Fourth, that the library data condition is not limited by time and space (Zed, 2014).

The steps in this research refer to the literature study steps proposed by Zed (2014), namely, first, the researcher prepares equipment in the form of pencils or pens and notebooks. For data accessed online, the researcher provides a laptop. Second, compiling a working bibliography. This work bibliography includes notes on the main source materials that will be used for research purposes, namely sources containing community empowerment and community potential. The sources referred to in the form of books, theses, theses, dissertations, research reports, scientific periodicals (journals and magazines), papers and writings in newspapers. Third, set the time. In this study, the researcher divided the time into two periods, namely finding sources and writing articles by giving a time span for each of these two weeks. Fourth, reading and making research notes.

\section{Discussion}

\subsection{Community Potential Based Community Empowerment}

Entering the new normal era, the implementation of community empowerment is required to adapt and change old patterns. If the previous community empowerment approach was like meeting with the community face-to-face and attended by many people, now it is starting to adapt by limiting each community meeting as well as additional health protocols that must be implemented in the village. Another change is the limitation of hours of activities outside the home, wearing a mask in every activity and always washing hands every time you go out of the house. One of the problems that is the focus of the solution is related to changes in the social order of life in the new normal life that occurs in people in Indonesia.

The decline in people's lives, the denomination is weakening, the number of employees being laid off due to the reduction of employees. Therefore, to overcome this problem, various efforts have been made and implemented. Efforts made so that the new normal can bring new life to the community in alleviating community powerlessness have begun to be encouraged by various sectors ranging from the government sector with its superior programs to Non-Governmental Organizations through efforts carried out whose goal is to reduce poverty and prosper the community (Mustangin, Kusiawati, Islami, Setyaningrum, \& Prasetyawati, 2017).

One of the efforts made by these various parties is through community empowerment. As described by Payne in Adi (2012), that community empowerment is intended to help others gain the power to make decisions and determine the actions they will take related to themselves, including reducing the effects of personal and social barriers. It is also mentioned by Widayanti (2012), that community empowerment is a public concern and is considered as one of the appropriate approaches in overcoming social problems, especially poverty, which is carried out by various elements ranging from government, business and society through civil society organizations.

Community empowerment action is an effort to provide power or strength for the community to get out of the problems it faces. Community empowerment actions are also intended to make people independent so they can face various challenges in their lives (Mustangin et al., 2017). According to Adi (2001), more defines empowerment activities as an effort to provide opportunities and abilities to community groups, in this case poor families are able to and dare to speak out in conveying their ideas and opinions and have the courage to choose either in the form of methods, products, actions and concepts that are considered best not only for the family and the person but also for the community.

To identify the above factors, there are several types of strengths that the community has and can be used to empower them. For example (power over personal choice) empowerment by giving people the opportunity to make personal choices or the opportunity to live a better life. (Power in determining their own needs) empowerment that is done by assisting them to formulate their own needs. (Power in freedom of expression) community empowerment is carried out by developing their capacity for free expression in the form of public culture. (Institutional Strength) empowerment is carried out by increasing community accessibility to educational, health, family, religion, social welfare systems, government structures, media and so on.

However, apart from all that, the purpose of community empowerment, according to Haris (2014), is; 1) it is intended that individuals, groups and communities have power over their lives; 2) Community 
empowerment activities are aimed at enhancing human dignity so that they are able to get out of the trap of poverty, powerlessness and all forms of backwardness. Thus, this helpless group can be independent and not always dependent on individual fiber from other groups to fulfill their basic needs; 3 ) Through activities in society, a change can be created for the better in all aspects of community life so that the quality of life and welfare of the community can be improved. 3) In order to achieve the objectives of community empowerment activities, there are several things that must be done including the need to develop a strong work ethic, be frugal, efficient, effective, accountable and appreciate the principle of openness. This is because behavior and culture like this have a very important role in encouraging and accelerating the process of change in society so that a strong, advanced and independent community is built in achieving the goals of community development.

Furthermore, in optimizing community empowerment through increasing community potential, it is necessary to carry out several strategies, namely; first selection of program targets; The area selection was carried out according to the criteria agreed by the community. Because all people are exposed to the covid-19 virus, people live in deprived or marginal conditions, determining program targets and types of activities according to community needs and potentials greatly determines the optimal implementation of community empowerment in the new normal era. Second, socialization of community empowerment programs. This activity is very important for creating communication and dialogue with the community. Socialization of empowerment programs to the community helps to increase understanding to the community and related parties about the program. The socialization process greatly determines the community's interest in taking part and being involved in community empowerment programs. Third, implementation of community empowerment programs. Community empowerment is carried out in the new normal era, it demands to be able to adapt and change old patterns. Whereas previous community empowerment approaches such as face-to-face meetings with large numbers of people are present, now they are starting to adapt by limiting each community meeting as well as additional health protocols that must be implemented. Another change is the limitation of hours of activities outside the home, wearing masks in every activity of the villagers and always washing their hands every time they go out of the house.

The new life order that exists in society will present challenges and opportunities that will exist in society. Opportunities include certain business sectors that have experienced an increase in income figures, such as health and medical, trade and online sales opportunities. However, behind several parties that have been able to reap large profits in this pandemic era, several other sectors have experienced a decline in income, layoffs by large companies without severance pay, restrictions on the space for people working outside the home.

Skills training is an effort to promote community welfare. People who have the skills or expertise in creating a powerful innovation and renewal will be able to improve people's welfare. In the current era of disruption, we are required to have skills, especially in the field of technology and have competence and be able to compete with other communities (Wafi, 2016). Therefore, it is necessary to prepare human resources (HR) who have skills and knowledge. One of the factors in preparing these human resources is through education that is taken from primary to tertiary education.

\section{Conclusion}

The Covid-19 pandemic has had a very significant impact on changing people's lives. Both from rural communities to urban communities. In this society. Demanded to adapt and change old patterns in social life, there has been a change in the village empowerment approach that was carried out in the past, such as face-to-face meetings with many people, now starting to adapt by limiting each community meeting as well as additional health protocols that must be implemented. Another change is the limitation of hours of activities outside the home, wearing a mask in every activity and always washing hands every time you go out of the house.

\section{References}

Adi, I. R. (2001). Pemberdayaan Pengembangan Masyarakat dan Intervensi Komunitas. Fakultas Ekonomi UI. 
Adi, I. R. (2012). Intervensi Komunitas \& Pengembangan Masyarakat: Sebagai Upaya Pemberdayaan Masyarakat. PT.Raja Grafindo Persada.

Akbar, M. W., \& Benedict, A. (2020). Kampanye di Tengah New Normal Era: Mampukah Kita Berdamai dengan Pandemi? (Makalah).

Arwani, M. (2020, June). Menakar New Normal Desa. Tribunjogja.Com.

Azizah, K. N. (2020, March). WHO Resmi Nyatakan Virus Corona COVID-19 sebagai Pandemi. Detikhealth.

Davina, D. (2020, March). Tak Terapkan Lockdown Pemerintah Kampanyekan Social Distancing, Apa Bedanya? Kompas TV.

Friana, H. (2020, March). WHO Umumkan Corona COVID-19 Sebagai Pandemi. Tirto.Id.

Habibi, A. (2020). Normal Baru Pasca Covid-19. 'Adalah: Buletin Hukum Dan Keadilan, 4(1), 197-202. https://doi.org/10.15408/adalah.v4i1.15809

Haris, A. (2014). Memahami Pendekatan Pemberdayaan Masyarakat Melalui Pemanfaatan Media. Jupiter, 13(2), 50-62.

Hasanah, F. A. (2015). Peran CSR PT. Sari Husada dalam Pemberdayaan Masyarakat. Universitas Islam Negeri Sunan Kalijaga Yogyakarta.

Hatta, R. T. (2020, March). Alasan WHO Tetapkan Virus Corona COVID-19 Sebagai Pandemi. Liputan6.Com.

Muhyiddin, M. (2020). Covid-19, New Normal, dan Perencanaan Pembangunan di Indonesia. The Indonesian Journal of Development Planning, 4(2), 240-252. https://doi.org/10.36574/jpp.v4i2.118

Mustangin, Kusiawati, D., Islami, N. P., Setyaningrum, B., \& Prasetyawati5, E. (2017). Pemberdayaan Masyarakat Berbasis Potensi Lokal Melalui Program Desa Wisata di Desa Bumiaji. Sosioglobal: Jurnal Pemikiran Dan Penelitian Sosiologi, 2(1), 59-72.

Nazir, M. (2014). Metode Penelitian. Ghalia Indonesia.

Prabawanti, M. A. H. (2020, June). Siapkan "New Normal”, Pemerintah Terus Fokus pada 3 Aspek Kebijakan. Kompas.Com.

Peraturan Pemerintah tentang Pembatasan Sosial Berskala Besar dalam Rangka Percepatan Penanganan Corona Virus Disease 2019 (Covid-19), Pub. L. No. 21 (2019).

Romi, D. (2020, March). Pemerintah Terapkan Social Distancing Ketimbang Lockdown. Sumeks.Co.

Simamora, J. (2020, August). Program Pemberdayaan Masyarakat di Era New Normal. Kompasiana.

Siregar, B. P. (2020, March). Pemerintah Pilih Social Distancing Ketimbang Lockdown. WartaEkonomi.Co.Id.

Sommaliagustina, D. (2020). 3 Epidemiologi New Normal: Antara Kesiapan dan Kegamangan (Makalah).

Sugiyono. (2016). Metode Penelitian Kuantitatif, Kualitatif, dan Kombinasi (Mixed Methods). Alfabeta.

Syaifudin, S. (2020, June). Negara, Masyarakat dan Era New Normal. Tempo.Co.

Taher, A. P. (2020, March). Pemerintah Ubah Istilah Social Distancing Jadi Physical Distancing. Tirto.Id.

Wafi, M. I. (2016). Pengaruh Pemanfaatan Sarana dan Prasarana Belajar Terhadap Prestasi Belajar 
Pendidikan Agama Islam Siswa Kelas X di SMA N 11 Semarang. Universitas Islam Negeri Walisongo.

Widayanti, S. (2012). Pemberdayaan Masyarakat: Pendekatan Teoritis. Ilmu Kesejahteraan Sosial, 1(1), 87-102.

Yahya, A. N. (2020, March). Pemerintah Ubah Istilah Social Distancing Jadi Physical Distancing. Kompas.Com.

Zed, M. (2014). Metode Penelitian Kepustakaan (3rd ed.). Yayasan Obor Indonesia. 